REFLECTIONS:

NEUROLOGY AND THE

HUMANITIES

Section Editor

Michael H. Brooke, MD

\section{Guns in the Afternoon}

Ludwig Gutmann, MD

Address correspondence and reprint requests to Dr. Ludwig Gutmann, Robert C. Byrd Health Sciences Center, P.O. Box 9180 , West Virginia University, Morgantown, WV 26506-9180 lgutmann@wvu.edu
Sam sat in the far corner of the bar, his sweat-marked Stetson hanging on a wooden peg above his head. The whiteness of his forehead ended abruptly just above his eyebrows. His face was wrinkled and dark from years in the prairie sunshine. He sat motionless, leaning against the timbered wall behind him, his chair angled so he could see across the whole room. Only his eyes were moving as he watched men playing card games at several tables, noisily arguing every hand, four miners drinking whiskey in complete silence at the other end of the long mahogany bar, and the women in tight skimpy dresses serving whiskey to the men at the tables. People who didn't know him sometimes had trouble meeting Sam's gaze-blue eyes washed out from the blazing prairie sun.

Sam glanced at a distant corner of the barroom where a man played a piano. The man was old, with the beginnings of a beard that probably wouldn't turn into anything. He wasn't much of a piano player, either. The Irish tune he played was barely audible above the complaints of the crowd. He had taken off his hat and upended it on the upright some time before, but no coins gleamed inside the black crown.

Sam's eyes kept coming back to a young man playing cards with some of the older cowhands. That kid, Sam thought, he still seemed a kid even though he was grown up now. That kid had a moustache, it was thin and scraggly and looked new and he wore a Colt 45 in a holster. The revolver was well cared for; the pearl handle gleamed in a shaft of sunlight that raked across the room.

Matthew, Sam thought. Matthew's life hasn't been easy. He had always lived with his mother in an old shack a few miles out of town. The night the boy was born, Sam had to go out to arrest the boy's father-at least, Mattie said he was the father-for threatening to kill the baby. Sam was a new deputy and that was his first arrest. The man he took into custody was drunk, as were most of the men who hung out at Mattie's place.

"I don't know what it is about me," she'd told Sam years later. "Every time I find a nice fella,' he turns out to be a drunk. Talk about bad luck."

Mattie was a woman whose smile was an attraction for men. She liked sitting on her front porch in a rocker, always waiting — so Sam thought—for some man to show up. She had three horses, eight head of cattle, and a goat that wandered about the open range surrounding the house, and she expected her boyfriends to feed and water them. When there was no one else to help, Matthew had to pitch in.

Matthew was her only son. "He's more than enough," she'd tell anyone who'd ask. "He's always in trouble. You'd think the sheriff and his deputies lived out here, the many times they have to come out."

Matthew often skipped school and, when he was there, he spent more time fighting than studying. Sam usually got to ride him home and not without some wrestling. Sometimes, though, they would talk. When Matthew turned ten, Sam taught him how to shoot a gun. Sometimes the kid seemed to be coming around and, at times like that, Sam figured he was the closest anyone got to being a father to the boy.

But the older Matthew got, the more irascible he became. He was getting to be as much trouble for Sam as his mother's drunken friends. Sam had told Mattie again and again that she needed to be firmer with the boy, but she would just laugh.

"There's no meanness in him- he's really a good boy," Mattie tried to assure him. At the rate things were going, Sam worried he would have to take the boy on when he got to be a man or even before.

"He's just as independent as his grandpap was," Mattie said. Yea, Sam thought when she said that, and what happened to that old man? He got shot in a bank holdup and ended up in the penitentiary.

Sam drank his beer slowly, rubbing his thigh, and watching Matthew playing cards. A woman leaned against his back, her breasts touching him lightly. Unlike the other women, she wore makeup like an actress. She gently messaged his back muscles, her hands moving to the rhythm of the Irish tune.

The kid is certainly a handsome fellow except for that moustache he's tryin' to grow, Sam thought. Doesn't look like Mattie, he's lean and trim and she's getting' fat. In fact, it's hard to believe Mattie is his mother. What's she going to do when she gets old? That kid's all she has.

Matthew worked as a cowhand for Chet Holcombe on a cattle ranch out in the county. Chet em- 
ployed a dozen cowboys to take care of the spread. He said Matt was a good worker, always full of energy and enthusiasm. He could lose his temper easily but, so far, it hadn't been a problem.

Sam looked down at his right leg and rubbed it again. The outside of his thigh burned so fiercely, he thought it might ignite his pants. It had been going on for a year and was just getting worse. It was now keeping him up at night. He was never much of a drinking man but he'd begun taking a shot of whiskey at night to help with sleep. He had finally gone to see Doc Sloan about it.

"It's all numb and burning in one spot," Sam said, pointing. "It's about the size of a one-egg frying pan. I can put up with the numbness but the burning is tough to take."

Doctors in the early west had the same difficulty all doctors had then-there weren't many drugs to help with problems and the problems, except for the simple ones, were often not understood. Setting a broken bone by touch alone, prescribing laudanum for pain, a few stomachache remedies of dubious merit, these few were the arsenal. But Doc Sloan had something else in his kit. He was a canny observerhe could come up with answers even when he didn't fully understand the questions.

The Doc had seen Sam approaching all the way across the street. By the walk he could tell Sam was in pain, and he knew why. "I've seen that before," Doc said after the exam, "especially in them lean gunslingers."

Sam's forehead wrinkled into a frown. "Ain't never been a gunfighter," he said.

"I know sheriffs ain't gunfighters even though you're pretty quick with that iron of yours." Doc ran his hand through his hair and stood up from his chair as he always did when he was about to say something serious.

He looked down at Sam. "I think what's happened is that that gun belt of yours with that pistol and ammo weighing it down is what's giving you the trouble." He picked it up from the back of the chair and hefted it. "You ain't got enough fat on you to hold up such a weight. Leather's heavy and that holster alone weighs a lot. The boys with more meat on' em don't have the problem you have, I seen it over and over again."

"Can you fix it, Doc?" Sam asked.

"It'll get better by itself if you quit wearing that gun belt of yours."

"How do I do that and keep being sheriff?" Sam asked.

"Well, you can carry your gun on the other leg for a while, but you better learn to shoot with your left hand," Doc said, and sat down, turning the chair around so he was facing his desk. Sam knew it was time to leave. Doc had spoken and there wasn't any other answer.

As Sam sat in the bar he reflected on Doc's analysis. Smart old coot, he thought, sees a lot of stuff and talks with a lot of people and sometimes figures it out. He'd visited Doc the week before and had been working on shooting with his left hand ever since. He'd always been able to use his left hand pretty fine, so he was accurate with his shots- his aim was as good as ever-but he couldn't draw the gun out quite fast enough. Without that instant reflex, he knew he'd come out second best in a gunfight.

Matthew concentrated on the card game. The woman standing behind him kept filling up his whiskey glass. He would occasionally reach back and pat her-she might go to bed with him tonight—but the real business right now was winning at poker.

Sam's gun belt lay next to his beer on the polished bar. He'd gotten in the habit of taking it off whenever he could. He didn't want to end up hurting his left leg same as the right one. Sam took a swallow of beer and touched his holster. The leather had gotten soft after years of rubbing and use. I'm getting' soft with age too, Sam thought. The burning in his leg was no better but Doc Sloan had said to give it time.

Sam finished his beer, slung the gun belt over his shoulder, and pushed his way out through the swinging doors. There had been no rain for weeks-even the horse droppings on the street were dried up. His boots kicked up miniature clouds of dust as he stepped off the boardwalk and walked across the sunbaked dirt street to his office. Posters announced a cattle auction coming the next month to be held there, in the wide unpaved town square. Can't have cattle and unshod range horses on cobblestone streets like in the city, Sam thought, but I sure hope it rains by auction time.

Paperwork was done quickly and Sam, bored, must have been dozing at his desk. For a brief instant, he thought the gunshot was part of his dream. At the second shot, loud and clear, he was out of his chair. He knew it was from the saloon. One of his deputies was running across the street. The frightened look on the deputy was enough for Sam-he knew someone was hurt, if not killed.

Sam strapped on his gun belt as he ran and headed for the door. "Get over to Doc Sloan's office," he yelled. "Tell him to get over here pronto."

The saloon was as quiet as the church down the street on Sunday during the silent prayer. Everyone watched Sam as he strode through the entryway. The only sounds were the soft squeak of the swinging doors and his heels clicking on the wooden floor. Matthew stood in the middle of the room behind the 
overturned card table, still holding his gun, a wisp of smoke rising from its barrel.

"Put the gun down, Matthew," Sam said. A man he didn't recognize was lying on the floor, holding his knee. Blood was seeping from two holes in his pant legs.

"He couldn't keep his hands off Tina," Matthew said, his speech slightly slurred. Matthew's girlfriend of the afternoon stood right behind him. "I told him to let it be. I gave him three chances and then I'd had enough."

"Put down the gun, Matthew," Sam repeated. Matthew dropped it into his holster and stood still, watching.

Doc Sloan came through the doorway carrying his black medical bag, the deputy right behind him. The doctor stepped to one side and so did the deputy. They both knew the game was not over yet.

"OK," Sam said to Matthew, "Let's walk over to my office while Doc takes care of things here."

Matthew swayed gently, his hands dangling loosely at his side. "I ain't coming with you, sheriff. If you want me, you'll have to take me." Looking at Tina, he added, "You better move away."

The center of the big room suddenly emptied out as people backed away, crowding themselves against the bar and the opposite wall. The piano player, hat in hand, disappeared into a back room. Two women slipped out through the swinging doors. Sam groaned silently to himself. That boy can outdraw me even if he is full of liquor, he thought. The late afternoon sunlight streaming through the open window gave Sam's dusty boots a shimmering brightness. A look of patience seemed painted on his immobile face. The stillness of the afternoon was broken by a whimper from the man on the floor.

"We got one person hurt, Matthew," Sam said, his voice just above a whisper. "We don't need two. Let's go across the street."

"Sheriff, you've always been good to me and my Mom," Matthew said. His arms hung loose at his sides. "I'm sorry it's come to this."

Matthew's index finger twitched. Sam knew the moment had arrived.

Both men drew. The young man's gun was already pointed straight at Sam's chest while the older man's had just cleared his holster. The explosion never came. Matthew's gun stayed frozen in midair.

"I can't do it, Sher ...," Matthew began to say.

Sam lowered his gun as it went off.

Matthew slumped into a chair, blood oozing from the top of his boot. "I shouldn't have drawn on you, Sheriff ..." He trailed off, tears streaming down his face.

Sam walked over toward him, still holding the gun in his left hand. Matthew was as fast as ever but Mattie was right, there was no meanness in him.

Sam patted the young man's shoulder. "Doc'll fix it up." There was a faint smile on Sam's face. He was proud of the kid. 


\title{
Neurology
}

\author{
Guns in the Afternoon \\ Ludwig Gutmann \\ Neurology 2009;72;939-941 \\ DOI 10.1212/01.wnl.0000344178.60536.8f
}

\section{This information is current as of March 9, 2009}

\section{Updated Information \&} Services

\section{Subspecialty Collections}

Permissions \& Licensing

\section{Reprints}

including high resolution figures, can be found at: http://n.neurology.org/content/72/10/939.full

This article, along with others on similar topics, appears in the following collection(s):

Neuropathic pain

http://n.neurology.org/cgi/collection/neuropathic_pain

Peripheral neuropathy

http://n.neurology.org/cgi/collection/peripheral_neuropathy

Information about reproducing this article in parts (figures,tables) or in its entirety can be found online at:

http://www.neurology.org/about/about_the_journal\#permissions

Information about ordering reprints can be found online:

http://n.neurology.org/subscribers/advertise

Neurology ${ }^{\circledR}$ is the official journal of the American Academy of Neurology. Published continuously since 1951, it is now a weekly with 48 issues per year. Copyright. All rights reserved. Print ISSN: 0028-3878. Online ISSN: 1526-632X.

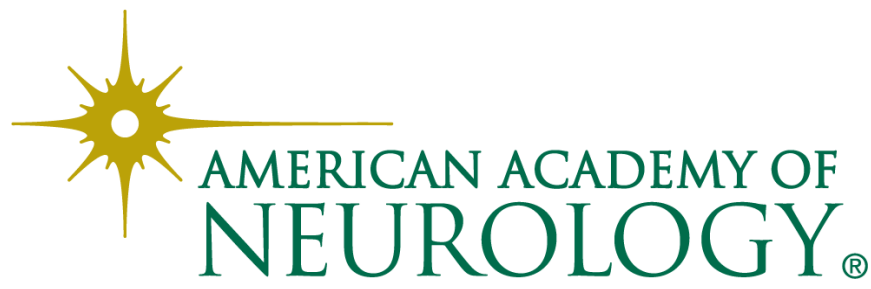

